\title{
Really Trapped in the Heat?
}

\section{Accounting for Occupants' Efforts in Panel Apartment Blocks}

\author{
Béla Janky ${ }^{1,2}$, János B. Kocsis ${ }^{1,3 *}$ \\ ${ }^{1}$ Department of Sociology and Communication, Faculty of Economic and Social Sciences, Budapest University of Technology and \\ Economics, H-1111 Budapest, Egry J. u. 1, Hungary \\ ${ }_{2}^{2}$ Centre for Social Sciences, Hungarian Academy of Sciences Centre of Excellence, H-1097 Budapest, Tóth Kálmán utca 4, Hungary \\ ${ }_{3}^{3}$ Department of Geography, Geoeconomy and Sustainable Development, Institute for International, Political and Regional \\ Studies, Corvinus University of Budapest, H-1093 Budapest, Fővám tér 8, Hungary \\ *Corresponding author, e-mail: kocsis.janos.balazs@gtk.bme.hu
}

Received: 05 September 2018, Accepted: 24 November 2020, Published online: 21 October 2021

\begin{abstract}
This paper aims to account for the role of occupants' efforts in reducing the space-heating costs of panel apartments linked to district heating systems. We present the findings of a questionnaire survey among residents of North-West Budapest (Hungary). Our results show that the roles of efforts are limited in the panel housing context, but wider access to appropriate information on those (limited) opportunities could significantly alleviate the burden on households trapped in an inadequate space heating regime.
\end{abstract}

\section{Keywords}

energy efficiency, panel apartments, district heating, reducing household costs

\section{Introduction}

From the early sixties on, fast industrialisation gave rise to urban districts of large panel apartment blocks all over state-socialist Central- and Eastern Europe. In the last decade of the $20^{\text {th }}$ century, about 170 million residents lived in 53 million flats in such apartment blocks in estates of more than 2,500 dwellings in the region of 375 million people $^{1}$ (Knorr-Siedow, 1996). In certain metropolitan areas, panel dwellers account for circa $80 \%$ of the local population $^{2}$ whereas this ratio is one third in Budapest.

Lack of energy efficiency stands out among the burdens this type of housing poses on residents and governments alike. Since the early nineties, post-communist governments have addressed the challenge by investing in retrofit programmes and providing consumer subsidies. In states that have been able to join the European Union, EU structural cohesion programmes have added

\footnotetext{
1 The numbers are 11 million dwellings homing 34 million people from a total population of 110 million, in the area excluding the countries of the former Soviet Union. The number is 20 million, including also the ones in estates smaller than 2,500 dwellings
}

$282 \%$ in Bucharest and $77 \%$ in Bratislava. their own contribution to the efforts already being made. Various strategies were applied, but none of them could fully cope with the task of replacing or modernising such a huge stock of real estate. Recent EU objectives (European Comission, 2012; European Parliament, Council of the European Union Directive 2009/28/EC, 2009) set in place ambitious targets for reducing $\mathrm{CO}_{2}$ emission in the built sector, by $20 \%$ by 2020 and by $75-90 \%$ by 2050 , the achievement of which would require huge and costly investments in the renovation of the existing stock, rendering the issue of appropriate strategies even more salient. Besides being a strategic question at both a national and a European level, reducing energy consumption is an important question at a household level as well; and the scarcity of public funds requires the involvement of private efforts to the highest possible extent.

Recently, Herrero and Ürge-Vorsatz (2012) have drawn attention to the harmful social consequences of inefficiencies stemming from the obsolete district-heating systems and insulation solutions. Their paper highlights the trap that leads to a special type of fuel poverty: adequate space heating at an inadequate price. In this way, they follow a line 
of research which takes a pessimistic view on the potential role for economical individual efforts in reducing the costs of space heating in such large panel apartment blocks.

Still, local policymakers, NGO-activists and eurocrats overseeing urban planning programmes are enthusiastic enough about promoting changes in household behaviour (Poortinga et al., 2004). Info-campaigns are parts of several programmes addressing energy-efficient housing in panel-districts. Among others, the EnSURE project, which analyses the potentials of energy efficient urban development at a local level, puts a strong emphasis on stimulating residents' efforts, partly through info-campaigns and info-points.

This paper aims at accounting for the role of occupants' efforts in reducing space-heating costs of panel apartments. We present the findings of a questionnaire survey among residents of North-west Budapest (Hungary). Our results show that such efforts play quite a limited role in the panel housing context, but that wider access to appropriate information on those (limited) opportunities could nevertheless significantly alleviate the burden on the households trapped in an inadequate space heating regime.

In the next section, we shed light on the sources of a specifically post-communist type of fuel poverty among panel dwellers. We present the data and the methods used in Section 3 and show our findings in Section 4. A discussion of policy lessons follows.

\section{Panel apartment blocks in the post-communist Central- and Eastern Europe}

Housing estates were a favoured method of housing in the post-communist countries due partly to ideological, and partly to practical, reasons. It apparently offered an adequate and prime means of modernisation, creating so-called "socialist" human beings as well as implementing a quick, massive and labour-effective method of construction during times of severe housing shortage. As part of elementary welfare policies after the death of Stalin, large housing programmes that were started during the latter part of the 1950s materialised in the form of gigantic housing estates. Despite political targets and needs being broadly similar, the ratio and average size of these estates varied substantially from country to country, reflecting local social, historical and political characteristics.

Enlargement of the housing stock and the ratio of prefab bousing estates was especially significant in the 19651985 period in Hungary as a consequence of the first fifteen-year housing programme (Berey, 1994). Large-scale housing estates sprang up mostly from the early 1970s
(Kocsis, 2012) that the public mostly identifies as "typical socialist form of housing".

The number of dwelling units in housing estates is put at more than 20 million in the countries of the former European communist bloc, excluding the ex-Soviet Union. Naturally, housing estates concentrate mostly in the cities and new towns; and the ratio of inhabitants living in such dwellings comprises $82 \%$ in Bucharest, $77 \%$ in Bratislava, $56 \%$ in Warsaw, $60 \%$ in Sofia, and $42 \%$ in Prague. In Budapest, this ratio is $33 \%$, and about $40 \%$ of all such dwellings in Hungary are situated in the capital, rendering the situation of prefab buildings rather an important issue.

In the early decades, the quality of the buildings played a secondary role in comparison with their sheer number. The energy consumption of the buildings was also marginal, as the energy supply seemed abundant and cheap and proper construction would have required relatively more financial investment; thus, insulation was inadequate, and flats were breezy. For cheaper construction costs, columns of blocks were built with a singular heating pipe in cascade connection, barring any possibility of heating regulation in a particular flat ${ }^{3}$. The prevalent technology of the housing estates, especially after 1960 (and after 1966 in Budapest) was the prefabricated concrete block technology; it required the least planning and offered the fastest means of mass production, although it was the most expensive (Kocsis, 2012), and other methods still remained in $u^{4} e^{4}$. The allocation of housing, however, created more, especially social, differences among the estates than the construction method. Briefly, except for a handful of prestige developments of the late 1980s, the earlier the housing estate was built and more favourable its location $\mathrm{was}^{5}$, the higher its average social composition became (Csizmady, 2002).

3 In case of a cascade connection, regulating the consumption in a flat would have meant the regulation of the entire line, and in addition, the outlet of the upper flat was the inlet in the one below due to the one-pipe system, thus extremely high heating was necessary on the upper floors to guarantee the sufficient heating on the lower ones.

4 In the earlier decade, estates had been built with the "traditional" method (using mostly brick), and in the entire period, cast-in-place concrete wall, monolithic concrete space structure, and various sorts of framework technologies were used since the early 1950s.

5 These two correlate heavily as the later, usually bigger, estates needed more empty land, available usually in the outer areas.

6 In fact, changes in the hosing allocation policies and fall in the public prestige of the housing estates had major effects on the social composition in the early 1970 s. 
Due to massive state subsidies, the cost of housing, including both the tenure or loan and housing maintenance, in the housing estates used to make up only a fragment of total income of the households; however, the situation abruptly changed after 1989 with the introduction of market prices. Large groups became housing poor, that is to say, their income might seem adequate, but the ratio of housing maintenance expenditures now made up 40-60 per cent of their income (Kocsis, 2004). The situation today is most severe in the case of heating, although theoretically it could offer the best means of cost-reduction, but the old cascade pipe systems do not allow any regulation on the household level, so all households are required to pay a rather high constant monthly fee ${ }^{7}$ according to the size of the flat, not to their consumption. Modernisation, such as insulation and parallel - and thus adjustable - heating pipe systems, offers a way to ease the burdens of the household but due to the architectural characteristics of the building 8 , the measured consumption is only one, albeit basic, variable in the equation calculating the fee.

Energy efficiency has become critical issue in the last thirty years for multiple reasons, at a national level (Szlávik et al., 2000), and specifically with regard to the condition and sustainability of housing estates in Hungary (Benkő, 2015; Kovács et al., 2018). From a strategic perspective, the country is heavily reliant on imports of oil and gas from a single source, namely Russia, without significant alternative routes where increasing energy efficiency could offer a means to loosen dependency (Selei et al., 2017). Extensive and superfluous use of energy resources, and a growing need for consumption together pose a significant environmental issue, both in general and in the urban environment in particular, representing an issue predominantly for municipalities (Rezessy et al., 2006). Energy poverty arises as an issue at the household level where decreasing consumption results in lessening the perils of deprivation. The situation and reduction of energy poverty became a focal point especially after the economic crisis in 2008 in Europe (Kolokotsa and Santamouris, 2015), and in former socialist countries (Jiglau et al., 2020). Households are specifically vulnerable in housing estates where the social composition and

7 Heating alone may count up to more than half of the net minimal wage in non-modernised average $\left(50 \mathrm{~m}^{2}\right)$ flats.

8 For instance: heat-insulation does not exist between the flats, thus one heated flat warms the next non-heated; flats with more external surface area have higher energy loss, etc. the characteristics of the building technology exacerbate the difficulties.

Residents in low status housing estates are entrapped in several ways. First, the high monthly housing maintenance expenditures serve to thwart any attempts they might make at collecting substantial funds with a view to paying for modernisation. Second, due to the low prestige of the housing estate, they cannot sell their homes to move to cheaper housing. Third, the overwhelming majority of houses the estates have turned into condominiums, thus rendering the decision-making process very difficult. On the whole, central (municipal or national) initiatives and financial participation are essential to the success of modernisation programmes.

Two major sorts of subsidies are targeted towards relieving energy poverty. On the demand side, local municipalities may grant monthly housing subsidies or occasional subsidies for applicants who are in arrears in paying the bills. On the supply side, large-scale programmes have been introduced to assist the energetic rehabilitation of buildings in housing estates. Typically, these programmes involve the equal financial participation of central and municipal funds and residents' own resources?. Government funds are also available for other housing types, but they are much smaller in scale ${ }^{10}$.

Óbuda, a north-western district with about 125,000 inhabitants has a varied landscape and a variety of housing types. It has a small, traditional area originally built in the $19^{\text {th }}$ century in its southern parts, connecting larger developments of tenement houses dating from the interwar period and condominiums from the socialist era, mostly found along on the flat areas along the River Danube and extensive, suburban and "rurban" types of areas of family homes farther up north along the river and scattered on the slopes of the Buda Mountains. However, almost $80 \%$ of its inhabitants live in four large panel housing estates established in the seventies and eighties, which are by no means uniform and contain all fundamental housing types. The differences are clearly reflected in the property market positions occupied by various large panel housing estates in our sampling area (Fig. 1, Budapest University of Technology and Economics, Department of Sociology and Communication, 2011).

9 A similar system is in use for more general rehabilitation condominiums, typically in pre-1945 tenement blocks.

10 The preference of housing estates in governmental programmes stem from easier application and simpler technological challenges there. 


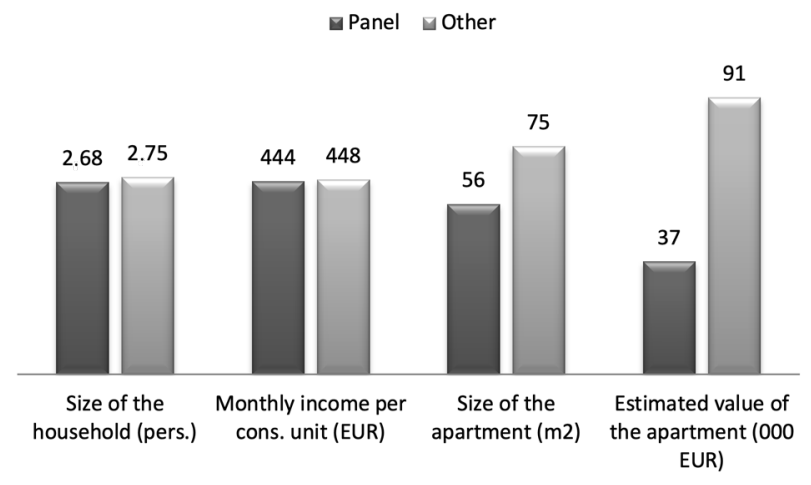

Fig. 1 Basic socio-economic and housing characteristics of households in Óbuda (Source: Own calculations based on EnSURE Household Survey of Óbuda (Budapest University of Technology and Economics, Department of Sociology and Communication, 2011) (weighted data). EUR $1=$ cca. HUF 270 in 2011. OECD's adjusted consumption unit scale: Consumption unit $\left.=1+\left(N_{\text {adults }}-1\right) \times 0.5+N_{\text {children }} \times 0.3\right)$

The Village Block (Faluház) project (Kocsis, 2013), a renovation of 884 flats, $43,500 \mathrm{~m}^{2}, 15$ staircases in one long building, was a flagship project of the local municipality, aimed at demonstrating sustainable technologies in renovation projects ${ }^{11}$. As a consequence, the energy consumption of the dwellings nearly halved. Since its finalisation, important issues have arisen regarding technological aspects, such as overproduction of warm water in summer, ventilation and dampness; and monetary aspects, such as the justifiable splitting of fees into fixed and consumption-dependent parts ${ }^{12}$. For better dissemination of information regarding energy efficient housing reconstruction for homeowners in the district, an InfoPoint was set up in the Village Block, run by Energy Club, an NGO. Besides, energy displays have been introduced in the Block and other areas of the district to show the inhabitants the results of the reconstruction.

Due to the high investment costs, some techniques may not be transferred mechanically to other buildings, but the main conclusions and many elements may prove useful in the on-going local, and national, renovation programmes.

In this paper, we aim at addressing the question: Is there a significant space for households' own efforts to diminish space-heating costs?

11 During the reconstruction in 2009, the outer walls were insulated, windows were replaced with energy-efficient ones, $1500 \mathrm{~m}^{2}$ of solar collectors (1128 $\mathrm{mWh}$ ), equivalent to $33176 \mathrm{Nm}^{3}$ of natural gas, were placed on the roof to provide the house with warm water.

12 Due to the low level of insulation between the flats, the heating of one flat warms significantly the others, rendering heating in some flats often unnecessary.

\section{Data and methods}

We analysed a questionnaire survey carried out among residents living in District 3 (Municipality of Óbuda). The fieldwork was completed in February 2011, as a part of a complex research programme within the framework of EnSURE programme to explore the opportunities of the local government for supporting sustainable urban development. The questionnaire was designed to shed light on households' efforts and occupants' attitudes. It addressed the major aspects of household energy use and included some attitude items and questions on the basic household characteristics and the respondent's socio-economic status. Our aim was to connect housing characteristics, socio-economic status, attitudes and actual efforts to improve energy efficiency.

Fieldworkers conducted 503 face-to-face interviews. We adopted spatially stratified sampling method to control for the variance in housing characteristics. Areas dominated by large housing estates were under-represented in the sample so as to increase the variance. Within each stratum, random-walk sampling design was implemented ${ }^{13}$. Altogether, 200 of our respondents live in one of the large panel estates in Óbuda. 50 interviews were completed in each of the four housing estates in the district. For the descriptive statistics, we used weighted data (based on official population statistics on the community) ${ }^{14}$.

The key variable is the average monthly payment for the district heating bill of the household. Only a handful of participants refused to provide this information or did not know the answer to this question.

We adopted OLS linear regression technique to explore the determinants of household level costs of space heating. Moreover, we also used similar models to explain the variance in the sum of the monthly electricity bill, and to compare those findings to the ones on space heating. Regressors include indicators on housing characteristics, household income, socio-demographic characteristics, and, finally, environmental attitudes.

In our regression estimations, we distinguish between the four housing estates in the area (see Section 2 for reasons) by adopting three dummies. Occupants of larger, taller apartment-block are more likely to suffer from inconveniencies

13 The sampling was designed and supervised by the research team at the Budapest University of Technology and Economics while the fieldwork was carried out by H-Reports, a professional pollster firm.

14 We are indebted to Péter Brózik for carrying out the weighting proccess. 
related to the district-heating system. Therefore, we separate tall buildings from smaller ones. However, there are significant technological differences between apartment-blocks of the same size in the same housing estate. We can control for one important phenomenon directly, namely, the occurrence of uncontrollable overheating (resulting in higher bills). A further crucial block-level determinant of energy use is the participation in retrofit programmes. We treated this indicator as an exogenous characteristic, rather than a signal of household-level effort.

Household level determinants of energy use include the size of the household (counted in OECD consumption unit), the size of the apartment, and household income. All of them might influence demand for space heating and sensitivity to its costs.

A crucial block of variable consists of the indicators on household level efforts for saving on space heating costs. Undoubtedly, private financial investments in modernising insulation or lowering demand on heating energy are strong signals of individual efforts. We did notice items addressing such efforts. However, overall too much data is missing on exact expenditures, so we can use only a dummy indicating an estimate regarding such recent investments.

From the point of view of our study, the key explanatory variables are those relating to information seeking. An item-block addressed the sources the respondent looked for information on opportunities for saving on energy expenditures. We incorporated a simple index signing the number of sources the respondent's household used in recent years.

Nonetheless, many everyday efforts are untouched by the above variables. We decided to use some proxies that indicate occupants' concern for energy saving. Two variables measure attitudes as proxies for behavioural patterns. Understandably, we measured the respondents' attitudes only, so they represented their full household in the case of those variables.

The New Ecological Paradigm (NEP) scale (Dúll and Janky, 2011; Dunlap et al., 2000) was used as one of the indicators of environmental attitudes. The current validity of this relatively old scale of 15 items has been widely discussed in the literature (Bernstein and Szuster, 2019). Nonetheless, it has continued to be used in recent years (Ntanos et al., 2019; Park et al., 2018) and proved to be a valid measure of environmental concerns in our sample as well. We carried out explorative factor-analysis to extract a proxy for general environmental awareness. The factor score of the un-rotated first factor created by a principal component method was then adopted as an independent variable in our regression models. The communality of this first factor is $30 \%$. This finding is in line with the results obtained by Dunlap et al. (2000), whose approach was based on a questionnaire survey conducted in Washington in 1990. Another, much simpler item indicates the respondent's support for higher public spending for environmental protection (even at the cost of higher taxes). And, finally, in those cases where some effort still remained unmeasured, we incorporated expenditures on electricity as a proxy for undetected activities aiming at saving on space heating costs (as well). Nonetheless, since spending on electricity is relatively strongly related to housing and household characteristics, its incorporation into the effort model would lead to misleading results. Therefore, we included it only in the full model, which controls for housing and household characteristics.

\section{Results}

As we have seen in Section 2, panel-block residents in Óbuda are of similar socioeconomic status as occupants of other housing types in the same community. The major difference between the two groups is the housing type itself: panel dwellers live in smaller, less comfortable and less valuable apartments. Herrero and Ürge-Vorsatz (2012) emphasise that panel-block occupants tend to face a special type of fuel-poverty, prevalent in post-communist societies.

Our data, indeed, also give some support for their findings, and provide evidence for a special type of fuel poverty. This is a kind of relatively deprived status. Paneldwellers do not spend more on space heating than other residents in the same area (EUR 89 vs 86). What is more, they have lower overall expenditures on power and fuel (EUR 154 vs. 171). One should note, however, that panel apartments are much smaller and have much lower market value than average apartments of different types in the same district. That is, families living in those large panel estates are really trapped in the heat: inevitable overspending on space heating makes it hard to move to larger apartments in two ways: inhibiting saving and harming the market value of those panel-apartments.

We have tried to account for the relative role of panel-dwellers' individual efforts in space heating costs in three ways. First, we compare the size of its impact to the ones of housing- and socio-economic characteristics. Second, we look at the effect of efforts on space heating costs among non-panel dwellers as well. Finally, we also investigate determinants of electricity use among panel-dwellers. 
Let us turn to the explanation of panel-dwellers' space heating costs. Three separate models estimate the effects of housing characteristics (Table 1, Model 1), socio-economic status (Model 2) and individual efforts (Model 3) among panel-dwellers, respectively. These models make it possible to compare the effects of the three major explanatory factors. Note, however, that only the full model (Model 4) provides proper estimations on the effects of the individual variables $^{15}$. One can see (Table 1, Model 3) that occupants' efforts may have a sizeable impact on space-heating cost. The estimated size is comparable to the ones of the effects of housing (Model 1) and status (Model 2).

As far as the household level efforts are concerned, private investments in modernising insulation etc. can help to reduce space-heating costs. Nonetheless, typical public (or, at least, condominium level) retrofit programmes lead to larger scale savings than private ones.

One should also note that looking for more information on savings opportunities can pay off. Its effect can be comparable to that of a typical retrofit programme.

Where attitudes are concerned, the simple item on support for public spending on environmental protection is a much stronger proxy for everyday concern than the complex index of general environmental attitudes. Nevertheless, the former variable only distinguishes between a small, engaged minority and the rest of the population.

How large is this effect of the occupants' efforts? For a comparison, we run our regression models of space heating costs also on the sample of local non-panel residents. The full model in this case has an inevitably smaller explanatory power. This is so because there are much larger differences across non-panel housing units than among panel-blocks, and we did not even try to capture this variety. However, the role of efforts among nonpanel dwellers can be compared to the one of panel-block occupants. Our data show that panel dwellers' efforts pay off better than the ones of those living in other types of housing (Fig. 2).

15 One should be careful with interpreting individual parameters in Models 1-3, since they can be biased due to correlations between regressors belonging to different models. Most of the coefficients are smaller in the full model than in the partial model. However, when some confounding factors are negatively correlated with an explanatory variable, the regression coefficient related to the latter one could be larger in the full model than in the partial one. For instance, the estimated effect of uncontrolled overheating on space heating cost becomes significant when the size of the apartment is controlled for, because uncontrollable heating is more common in housing estates with smaller apartments.
Table 1 OLS linear regression estimates on space heating costs of panel dwelling households in Óbuda (Budapest)

\begin{tabular}{|c|c|c|c|c|}
\hline & Model 1 & Model 2 & Model 3 & Model 4 \\
\hline Constans & $20.342^{* * * *}$ & $8.250^{*}$ & $28.917^{* * * *}$ & 7.442 \\
\hline \multicolumn{5}{|l|}{$\begin{array}{l}\text { Housing estate (ref.: } \\
\text { Békásmegyer est.) }\end{array}$} \\
\hline "Central" estates & -1.133 & & & -0.934 \\
\hline Kaszásdűlő estates & $5.563^{* * * *}$ & & & 1.999 \\
\hline Pók utca estates & $6.363^{* *}$ & & & $6.345^{* *}$ \\
\hline $\begin{array}{l}\text { 10-storey apartment } \\
\text { block }\end{array}$ & $4.367^{* *}$ & & & $4.200^{* *}$ \\
\hline $\begin{array}{l}\text { Uncontrollable } \\
\text { overheating }\end{array}$ & 4.526 & & & $6.665^{* *}$ \\
\hline Public investment & $-4.722^{* * * *}$ & & & $-4.234^{* * *}$ \\
\hline Consumption unit & & 2.181 & & -0.750 \\
\hline $\begin{array}{l}\text { Size of the apartment } \\
\left(\mathrm{m}^{2}\right)\end{array}$ & & $0.205^{* * *}$ & & $0.173^{* * * *}$ \\
\hline $\begin{array}{l}\text { SQRT(Household } \\
\text { monthly } \\
\text { expenditures) }\end{array}$ & & 0.004 & & 0.014 \\
\hline Private investment & & & $-2.897^{*}$ & $-2.445^{*}$ \\
\hline $\begin{array}{l}\text { No. of info-seeking } \\
\text { sources }\end{array}$ & & & $-1.479^{* * * * *}$ & $-0.810^{*}$ \\
\hline $\begin{array}{l}\text { Factor score of } \\
\text { environmental } \\
\text { attitudes }\end{array}$ & & & -1.149 & -0.519 \\
\hline $\begin{array}{l}\text { Supports public } \\
\text { spending on } \\
\text { env. prot. }\end{array}$ & & & $-3.796^{*}$ & $-6.891^{* * *}$ \\
\hline $\begin{array}{l}\text { Monthly electricity } \\
\text { bill (thousand HUF) }\end{array}$ & & & & 0.347 \\
\hline$R^{2}$ & $20 \%$ & $9 \%$ & $14 \%$ & $35 \%$ \\
\hline
\end{tabular}

Note: Unstandardised coefficients. Dependent: average sum of the monthly space heating bill (thousand HUF; EUR $1=\mathrm{cca}$. HUF 270 in 2011). $N=190$ for all the 4 models. $* p<0.1, * * p<0.05$, *** $p<0.01$, $* * * * p<0.001$

Another kind of reference is the return on efforts of the same household in a different area, namely, electricity use. In this case the picture is more complicated (Fig. 2). In a

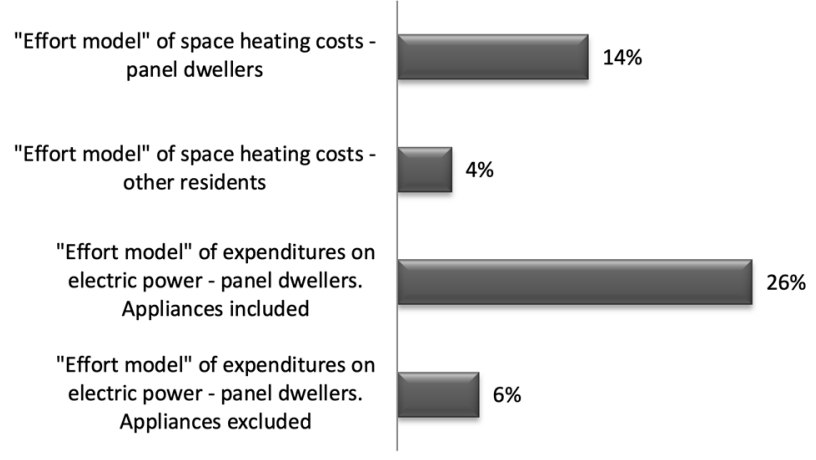

Fig. 2 Explanatory powers of OLS linear regression estimates of "effort models" on space heating and electricity costs (Note: For the effort model of space heating costs see Table 1) 
full model explaining electricity use, efforts seem to have a larger impact than is the case in the model of space-heating costs. Nonetheless, due to the larger costs of heating, a high level of effort (relative to low and average levels) in relation to space heating still pays off as much in absolute terms as is the case in relation to electricity use.

Access to appropriate information on savings opportunities is one of the key requirements for a high return on occupants' efforts. Numerous local policy-initiatives use assumptions which trace energy overconsumption of households back to lack of appropriate information. Consequently, let us look at the impacts of households' info-seeking activities in more detail.

Our questionnaire included a question on info-seeking activities, presenting 10 items of potential sources (from media to friends and special info-points). An average respondent turned to circa two types of sources in order to be more informed about energy efficiency. In the most active, upper quintile, the average is 4.45 types of sources per household. Nobody had looked for any information in the least active quintile.

There is a striking difference between the monthly space heating costs of the most and least active quintiles of households. The most diligent $20 \%$ of panel-dwellers spend about EUR 78 on space heating, while the inactive lowest $20 \%$ have, on average cca. EUR 107 of space heating expenditures. That is, ignorant households spend $37 \%$ more on space heating than those deliberately looking for information! One should note, however, that a kind of self-selection effect might largely overestimate the independent effect of new information on potential savings. We are getting closer to the effect of info-seeking by looking at the regression estimates. Nonetheless, even in the regression model, the coefficient of information seeking activity may also include some unmeasured behavioural characteristics.

The ceteris paribus difference (based on Model 4 in Table 1) between the most and least active quintiles (using 4.45 and 1.9 information sources on average, respectively is still noticeable. An otherwise representative household that hasn't looked for information on saving opportunities in recent years, spends $19 \%$ more on space-heating than the most curious $20 \%$ of the local panel-dwellers (EUR 96 vs. 81).
To sum up, occupants' efforts might play a significantly role in diminishing space-heating costs in panel apartments. Substantive significance is reinforced by using various types of reference points.

\section{Discussions and conclusions}

In this paper, we investigated the relative role of occupants' efforts in saving on space heating costs in panel apartments fuelled by district heating systems. We used several reference points to interpret the results of our OLS regression estimates on the effects of households' efforts. None of the comparisons we used are perfect. However, all of them indicate that occupants of panel-dwellings are not fully trapped in the heat. They have, to some degree, opportunities to alleviate the heavy burden the obsolete district-heating networks impose on them.

Nonetheless, decreasing space-heating costs in the current pricing-regime does not necessarily means a similar improvement in energy efficiency - due to the technical limitations of the district heating systems, which can hardly cope with increasing levels of overcapacity. One should not mix up the following three aspects of potential savings:

1. change in the heating costs paid by the household under the current regime;

2. change in the energy demand of the household; and

3. change in the heating costs (energy efficiency) per household connected to the same district-heating network.

Our findings show that providing information on saving opportunities might have a fairly significant role in influencing occupants' behaviour and moderating high space heating expenditures in panel apartment blocks. Nonetheless, it should be a part of a complex strategy, but it is not enough alone to cope with specific fuel-poverty experienced by panel dwellers.

\section{Acknowledgement}

The research forming the base of this paper was carried out within the framework of EnSURE, EU Central Europe Programme 2CE166P. 


\section{References}

Benkő, M. (2015) "Budapest's Large Prefab Housing Estates: Urban Values of Yesterday, Today and Tomorrow", Hungarian Studies, 29(1-2), pp. 21-36.

https://doi.org/10.1556/044.2015.29.1-2.2

Berey, K. (1994) "Housing Policy in Hungary", Periodica Polytechnica Social and Management Sciences, 2(2), pp. 85-95. [online] Available at: https://pp.bme.hu/so/article/view/6550 [Accessed: 17 May 20217]

Bernstein, J., Szuster, B. W. (2019) "The new environmental paradigm scale: Reassessing the operationalization of contemporary environmentalism", The Journal of Environmental Education, 50(2), pp. 73-83.

https://doi.org/10.1080/00958964.2018.1512946

Budapest University of Technology and Economics, Department of Sociology and Communication (2011) "EnSURE Household Survey of Óbuda", SPSS database based on 503 face-to-face interviews in April and May 2011 in District 3 of Budapest.

Csizmady, A. (2002) "Changes in the Real Estate Market Position of Housing Projects in Budapest After the Political Transformation in 1989", Review of Sociology, 8(1), pp. 37-54. https://doi.org/10.1556/revsoc.8.2002.1.2

Dúll, A., Janky, B. (2011) "Environmental Attitudes and Household Electricity Use among Budapest Residents", International Review of Social Research, 1(3), pp. 115-131. https://doi.org/10.1515/irsr-2011-0023

Dunlap, R. E., Van Lierre, K. D., Mertig, A. G., Jones, R. E. (2000) "New Trends in Measuring Environmental Attitudes. Measuring Endorsement of the New Ecological Paradigm: A Revised NEP Scale", Journal of Social Issues, 56(3), pp. 425-442. https://doi.org/10.1111/0022-4537.00176

European Comission (2012) "Energy Roadmap 2050", Publications Office of the European Union, Luxembourg, Luxembourg. https://doi.org/10.2833/10759

European Parliament, Council of the European Union Directive 2009/28/EC of the European Parliament and of the Council of 23 April 2009 on the promotion of the use of energy from renewable sources and amending and subsequently repealing Directives 2001/77/EC and 2003/30/EC.

Herrero, S. T., Ürge-Vorsatz, D. (2012) "Trapped in the heat: A post-communist type of fuel poverty", Energy Policy, 49, pp. 60-68. https://doi.org/10.1016/j.enpol.2011.08.067

Jiglau, G., Sinea, A., Dubois, U., Biermann P. (eds.) (2020) "Perspectives on Energy Poverty in Post-Communist Europe", Routledge, London, UK. https://doi.org/10.4324/9781003000976

Kocsis, J. B. (2004) "The Housing Poor in Budapest, Hungary: Situation and Perspectives", In: Fearn, J. (ed.) Too Poor to Move, Too Poor to Stay: A Report on Housing on the Czech Republic, Hungary and Serbia, Open Society Institute, Local Government and Public Service Reform Initiative, Budapest, Hungary, pp. 67-95.

Kocsis, J. B. (2012) "Lakáspolitika Budapesten 1960-1975 között: A szocialista lakáspolitika aranykora" (Housing policy in Budapest between 1960 and 1975: The golden age of socialist housing policy), Múltunk, 57(1), pp. 160-206. (in Hungarian)
Kocsis, J. B. (2013) "Energy efficient urban development on local level Lessons learnt for EnSURE project", presented at European Network for Housing Research, Tarragona, Spain, Jun., 19-22, 2013. https://doi.org/10.13140/2.1.4304.9764

Kolokotsa, D., Santamouris, M. (2015) "Review of the indoor environmental quality and energy consumption studies for low income households in Europe", Science of the Total Environment, 536, pp. $316-330$.

https://doi.org/10.1016/j.scitotenv.2015.07.073

Kovács, Z., Egedy, T., Szabó, B. (2018) "Persistence or Change: Divergent Trajectories of Large Housing Estates in Hungary", In: Hess, D. B., Tammaru, T., van Ham, M. (eds.) Housing Estates in Europe, Springer, Cham, Switzerland, pp. 191-214. https://doi.org/10.1007/978-3-319-92813-5_9

Knorr-Siedow, T. (1996) "Present and Future Outlook for Large Housing Estates", European Academy of the Urban Environment, Institute for Regional Development and Structural Planning. [online] Available at: http://www.eaue.de/Housing/housfut/htm [Accessed: 10 September 2012]

Ntanos, S., Kyriakopoulos, G., Skordoulis, M., Chalikias, M., Arabatzis G. (2019) "An Application of the New Environmental Paradigm (NEP) Scale in a Greek Context", Energies, 12(2), Article number: 239. https://doi.org/10.3390/en12020239

Park, E., Lee, S. Lee, C-K., Kim, J. S., Kim, N-J. (2018) "An integrated model of travelers' pro-environmental decision-making process: The role of the New Environmental Paradigm", Asia Pacific Journal of Tourism Research, 23(10), pp. 935-948. https://doi.org/10.1080/10941665.2018.1513051

Poortinga, W., Steg, L., Vlek, C. (2004) "Values, Environmental Concern, and Environmental Behavior: A Study into Household Energy Use", Environment and Behavior, 36(1), pp. 70-93. https://doi.org/10.1177/0013916503251466

Rezessy, S., Dimitrov, K., Urge-Vorsatz, D., Baruch, S. (2006) "Municipalities and energy efficiency in countries in transition: Review of factors that determine municipal involvement in the markets for energy services and energy efficient equipment, or how to augment the role of municipalities as market players", Energy Policy, 34(2), pp. 223-237. https://doi.org/10.1016/j.enpol.2004.08.030

Selei, A., Tóth B., Resch, G., Szabó, L., Liebmann, L., Kaderják, P. (2017) "How far is mitigation of Russian gas dependency possible through energy efficiency and renewable policies assuming different gas market structures?", Energy \& Environment, 28(1-2), pp. 54-69. https://doi.org/10.1177/0958305X16685471

Szlávik, J., Pálvölgyi, T., Füle, M., Ürge-Vorsatz, D. (2000) "Carbon Mitigation in Hungary: Challenges for a Sustainable National Energy Policy", Periodica Polytechnica Social and Management Sciences, 8(2), pp. 103-120. [online] Available at: https://pp.bme. hu/so/article/view/1744 [Accessed: 20 April 2016] 